\title{
From forest to cropland and pasture systems: a critical review of soil organic carbon stocks changes in Amazonia
}

\author{
KENJI FUJISAKI ${ }^{1,2}$, ANNE-SOPHIE PERRIN ${ }^{1}$, THIERRY DESJARDINS ${ }^{3}$, MARTIAL \\ BERNOUX ${ }^{2}$, LUIZ CARLOS BALBINO ${ }^{4}$ and MICHEL BROSSARD ${ }^{2}$ \\ ${ }^{1}$ Centre Technique Interprofessionnel des Oléagineux et du Chanvre (CETIOM), Etablissement Public Local d'Enseignement et de \\ Formation Professionnelle Agricole (EPLEFPA) de la Guyane, Savane Matiti, BP 53, 97 355, Macouria, Guyane française, France, \\ ${ }^{2} I R D$ (Institut de Recherche pour le Développement), UMR 210 EcoESols, Campus SupAgro, bât. 12, 2 place Viala, 34060 \\ Montpellier Cedex 02, France, ${ }^{3} I R D$ (Institut de Recherche pour le Développement), UMR 242 iEES Paris, 32 av. H. Varagnat, \\ 93143 Bondy Cedex, France, ${ }^{4}$ EMBRAPA Cerrados, Cx Postal 08223, CEP 73310-970, Planaltina, DF, Brazil
}

\begin{abstract}
The impact of deforestation on soil organic carbon (SOC) stocks is important in the context of climate change and agricultural soil use. Trends of SOC stock changes after agroecosystem establishment vary according to the spatial scale considered, and factors explaining these trends may differ sometimes according to meta-analyses. We have reviewed the knowledge about changes in SOC stocks in Amazonia after the establishment of pasture or cropland, sought relationships between observed changes and soil, climatic variables and management practices, and synthesized the $\delta^{13} \mathrm{C}$ measured in pastures. Our dataset consisted of 21 studies mostly synchronic, across 52 sites (Brazil, Colombia, French Guiana, Suriname), totalling 70 forest-agroecosystem comparisons. We found that pastures $(n=52$, mean age $=17.6$ years $)$ had slightly higher SOC stocks than forest $(+6.8 \pm 3.1 \%)$, whereas croplands $(n=18$, mean age $=8.7$ years) had lower SOC stocks than forest $(-8.5 \pm 2.9 \%)$. Annual precipitation and SOC stocks under forest had no effect on the SOC changes in the agroecosystems. For croplands, we found a lower SOC loss than other meta-analyses, but the short time period after deforestation here could have reduced this loss. There was no clear effect of tillage on the SOC response. Management of pastures, whether they were degraded/nominal/improved, had no significant effect on SOC response. $\delta^{13} \mathrm{C}$ measurements on 16 pasture chronosequences showed that decay of forest-derived SOC was variable, whereas pasture-derived SOC was less so and was characterized by an accumulation plateau of $20 \mathrm{Mg} \mathrm{SOC} \mathrm{ha-1}$ after 20 years. The large uncertainties in SOC response observed could be derived from the chronosequence approach, sensitive to natural soil variability and to human management practices. This study emphasizes the need for diachronic and long-term studies, associated with better knowledge of agroecosystem management.
\end{abstract}

Keywords: annual crop, carbon storage, chronosequence, deforestation, grassland, humid tropics, rainforest, soil organic matter, soil tillage, $\delta^{13} \mathrm{C}$

Received 20 September 2014 and accepted 5 January 2015

\section{Introduction}

The greenhouse gases (GHG) emissions associated with tropical land-use change were $1.1 \pm 0.7$ for the 2000 2007 period and are approximately equal to the total global land-use change emissions because carbon balance of land-use changes in temperate and boreal biomes is roughly neutral (Pan et al., 2011). Tropical deforestation is the largest contributor to these emissions. Biomass burning is the main source of $\mathrm{CO}_{2}$ emissions following deforestation, but deforestation also

Correspondence: Michel Brossard, tel. +33 499613080, fax +33 499 6121 19, e-mail: michel.brossard@ird.fr perturbs the soil carbon cycle, which is likely to cause a decrease in SOC stocks due to a decrease in carbon inputs to the soil (Lal et al., 1997; Smith, 2008), and to increased mineralization rates after crop establishment (e.g. Balesdent et al., 1998), However, there is large uncertainty about the fate of soil organic carbon after deforestation in tropical regions (Penman et al., 2003; Grace et al., 2014).

The Amazonian biome is an evergreen rainforest, largely conserved, which covers about 5.3 million $\mathrm{km}^{2}$ (Eva et al., 2005), and represents about $40 \%$ of the world's remaining tropical rainforest. This biome has been stable for millennia, although it experienced dry periods during the Holocene which transformed the 
forest into savannah at its periphery (Soubiès, 1979; Desjardins et al., 1996; Freitas et al., 2001). The Brazilian Amazonia represents $75 \%$ of the biome and is regarded as a sink for carbon, which is estimated at $+0.30 \mathrm{Gt} \mathrm{C}$ year $^{-1}$ for the 1980-2004 period (Aragão et al., 2014). However, since the end of 1960's, large parts of Amazonian forest were cleared and replaced by pasture and cropland. For Brazilian Amazonia, Nepstad et al. (2009) estimated that the deforestation rate between 1996 and 2005 was $19500 \mathrm{~km}^{2} \mathrm{yr}^{-1}$, releasing $0.38 \mathrm{Gt} \mathrm{C} \mathrm{yr}^{-1}$ to the atmosphere. However, the deforestation rate decreased from 2004 and was less than $6000 \mathrm{~km}^{2} \mathrm{yr}^{-1}$ in 2013, thanks to policies aimed at reducing deforestation (Nepstad et al., 2014).

Besides the critical importance of SOC dynamics in anthropogenic greenhouse gas emissions, the organic matter in tropical soils plays a major role in maintaining soil properties. A drastic decline in soil organic matter can degrade soil structure, lead to erosion and reduce agricultural productivity (Stocking, 2003). Deforestation can increase water erosion rates via the degradation of soil structure (Grimaldi et al., 2003), exporting SOC from fields and depleting the soil (Don et al., 2011). Apart from its effect on soils, deforestation in Amazonia causes major environmental disturbances: loss of biodiversity (Dale et al., 1994), habitat fragmentation (Skole \& Tucker, 1993), emissions of C, N and S compounds into the atmosphere during forest fires (Fabian et al., 2005), disruption of the natural cycle of mercury (Béliveau et al., 2009) and alteration of sediment transport in rivers (Farella et al., 2001). On a global scale, Amazon deforestation induces climate change, with a decrease in rainfall, increased insolation and changes in the hydrological cycle by reducing tree transpiration (Malhi et al., 2008).
In this context of global (climate change, land-use change, food security) and local (soil conservation at the field and watershed scales) challenges, it is crucial to understand the SOC storage dynamics associated with deforestation and agroecosystem establishment. Several meta-analyses of SOC stocks after land-use change have been made on a global and continental scale, and on the Amazon biome (Table 1). A quick overview of the results of these meta-analyses highlights some trends: forest conversion towards croplands generally lead to a decrease in SOC stocks, while trends are less obvious for forest conversion to pasture which can lead, depending on the meta-analysis, to a decrease in SOC stocks (Fearnside \& Barbosa, 1998; Don et al., 2011), to an increase (Guo \& Gifford, 2002) or to no significant change (Murty et al., 2002). The explanations for these variations in SOC stocks also vary according to the meta-analysis. For Amazonian pastures, Fearnside \& Barbosa (1998) interpreted that SOC variations were dependent on pasture management; Neill \& Davidson (2000) found that grass species and SOC stocks under forest could explain losses or gains of SOC after pasture establishment. At smaller scales, where climatic contrasts are greater, it was found that precipitation affected SOC dynamics after deforestation, although sometimes in opposite ways depending on the meta-analysis. Eclesia et al. (2012) showed that in South America, SOC stocks in pastures were positively correlated with mean annual precipitation (MAP). Guo \& Gifford (2002) found the same correlation on a global scale, but when MAP exceeded $3000 \mathrm{~mm}$, SOC stocks in pastures decreased. Don et al. (2011) showed that in the tropics the higher MAP and temperatures, the lower were the SOC stocks found in agroecosystems, due to increased rates of mineralization of organic matter under hot and humid climates.

Table 1 Meta-analyses on SOC changes after deforestation and agroecosystem establishment across the world

\begin{tabular}{lllll}
\hline Scale & $\mathrm{n}^{*}$ & SOC stock change (\%) & Depth $(\mathrm{cm})$ & Reference \\
\hline Amazonia & $10(\mathrm{~Pa})$ & $-17.8 \dagger$ & $10-20-30-100$ & Fearnside \& Barbosa (1998) \\
& & & \\
Amazonia & $14(\mathrm{~Pa})$ & +7.3 & $10-20-30$ & Neill \& Davidson (2000) \\
World & $170(\mathrm{~Pa})$ & +8 & & Guo \& Gifford (2002) \\
& $37(\mathrm{Cr})$ & -42 & & Murty et al. (2002) \\
World & $33(\mathrm{~Pa})$ & $+6.4 \pm 7.0$ & $36 \pm 3$ & Don et al. (2011) \\
Tropics & $31(\mathrm{~Pa})$ & $-22.1 \pm 4.1$ & $36 \pm 4$ & Eclesia et al. (2012) \\
South America & $93(\mathrm{~Pa})$ & $-12.1 \pm 2.3$ & 20 & \\
\hline
\end{tabular}

Pa, pastures; Cr, croplands.

*Number of comparisons forest-agroecosystem.

$\dagger$ Pastures with 'typical management'.

$\ddagger$ Pastures with 'ideal management'. 
Clay content of the soil does not explain SOC variation after deforestation (Neill \& Davidson, 2000; Don et al., 2011).

It seemed relevant here to update the state of knowledge on the fate of SOC stocks across the Amazon biome, for several reasons: (i) from the late 2000s a significant number of forest-agroecosystem comparisons have been published, including forest conversion to cropland (e.g. Maia et al., 2010). Croplands were absent from the meta-analyses published by Fearnside \& Barbosa (1998) and Neill \& Davidson (2000) since deforestation at that time in Amazonia aimed to establish mostly cattle pasture; (ii) to our knowledge, no recent study has synthesized the $\delta^{13} \mathrm{C}$ data measured in many Amazonian pastures, which are a useful tool for analysing the SOC dynamics, able to distinguish carbon derived from forest or from pasture; (iii) trends in, and reasons for, SOC variations after deforestation vary depending on the geographical scale (biome, continent, tropical areas around the world). This being so, a focus on the Amazon biome is valuable for two reasons. Firstly, this biome is characterized by a mean temperature with little spatial and annual variation, between 24 and $26^{\circ} \mathrm{C}$, but spatial patterns of precipitation are more variable (Nobre et al., 2009). This offers the opportunity to test the effect of annual precipitation on SOC variations after deforestation, rather than the global effect of climate characteristics. Secondly, despite of the variability of soil properties in Amazonia (Quesada et al., 2011), studies dealing with SOC after deforestation were made mostly on ferralsols and acrisols, deeply weathered soils all with low-activity clays. In contrast, in the whole humid tropics, this kind of study was made on a wider range of soils (see the review of Don et al., 2011), which could obscure the explanation of observed trends.

In this way, we analysed all the studies available in Amazonia where forest was replaced by an agroecosystem to:

1 determine whether any soil/climatic factors and/or agroecosystem management influenced SOC stocks variations after deforestation;

2 identify the main sources of uncertainties associated with SOC variations after deforestation; and

3 discuss the methodological implications for future research.

\section{Materials and methods}

\section{The Amazon biome}

The Amazon biome can be defined on ecological, climatic, topographic or hydrographic criteria. We chose those selected by Eva et al. (2005) and Cerri et al. (2006) and considered the studies conducted in the lowland Amazon Basin rainforest (Amazon and Tocantins basins, Guiana shield and Gurupí region). This area is formally denominated as the 'Entire Amazon lowland rainforest biome'. We excluded rainforest located above $800 \mathrm{~m}$ and also the southern part of the Brazilian Legal Amazon, covered by savannah (Cerrado biome). According to the Koppen-Geiger system (Peel et al., 2007), the climate subtypes in our regional selection are Af (no dry season), Aw (with dry season) and Am (monsoon type).

On this scale, typology and soil properties are dependent on the geological context and the climate (Quesada et al., 2011). Many geological features structure the pedological context: the Guianan and Brazilian shields in the north and the south of the region, composed of Precambrian plutonic and/ or metamorphosed acid rocks, the centre basin, with sedimentary tertiary deposits resulting from the erosion of the shields, and the west sedimentary deposits formed after Andean orogenesis. The hydrolysis of primary silicate minerals induces the formation of soil with a clay fraction dominated by kaolinite and iron and aluminium hydroxides. The deep geochemical weathering induces soil acidity $(\mathrm{pH}<5)$; there are no carbonate deposits, and the cation exchange capacity is generally less than $20 \mathrm{cmol} \mathrm{kg}^{-1}$ (Gardi et al., 2014). The soils mostly have a clayey ( $>60 \%$ of clay), sandy clay $(<40 \%$ of clay) or a sandy texture, the silt fraction only being found in the young sedimentary deposits. The main soil classes are Acrisols and Ferralsols (IUSS Working Group, 2007), with a few Podzols, Plinthosols and Alisols. Acrisols (Ultisols in the American taxonomy, Argissolos in the Brazilian taxonomy) are mainly observed on the Guianan and Brazilian shields and in the Andean piedmont. Ferralsols (Oxisols in the American Taxonomy, Latossolos in the Brazilian Taxonomy) are on the shields and in central Amazonia; they are deep, exhibit diffuse boundaries between horizons, and primary minerals are totally weathered. Plinthosols associated with Alisols are observed in the fluviatile deposits. Podzols are found in the north of the basin, their genesis being associated with the sandy sediments derived from the Palaeozoic Era (Horbe et al., 2004) and with lateral drainage (Do Nascimento et al., 2004), inducing a progressive transformation of the lateritic mantle (Fritsch et al., 2011). In regions dominated by intensively weathered soils, Ferralsols, Acrisols and Podzols, the surface waters are acid and black, due to dissolved organic matter associated with iron forms exported from the soil mantle (Bardy et al., 2011; Fritsch et al., 2011). Conversely, in the upper basin, white waters are dominant, indicating transport in suspension of fine minerals eroded from the Andean slopes. In this case, the exported carbon is partly associated with the clays (Pérez et al., 2011; Bouchez et al., 2014).

\section{Selection of data}

We selected studies within the Amazon biome that met following criteria:

1 They should measure SOC stocks after deforestation and pasture or cropland (annual crops) establishment. We neither considered the shifting cultivation systems, practiced 
by Indigenous population and characterized by multidecennial cycles of cultivation and secondary forest (Nepstad et al., 2009), nor agroforestry systems (oil palm, pepper, etc.);

2 If SOC stock data were not available, they could be calculated from SOC content and bulk density (e.g. Janssen \& Wienk, 1990). SOC stock could then be expressed for the forest and the agroecosystem on an equivalent mass basis (Ellert et al., 2007), to take account of the change in soil bulk density after deforestation (Grimaldi et al., 1993; Alegre \& Cassel, 1996; Don et al., 2011). If this correction was not performed in the original paper, we recalculated SOC stocks in the agroecosystem from the raw data, or considered the corrected SOC stocks calculated by Fearnside \& Barbosa (1998) for some chronosequences;

3 Sampling depth should be at least $20 \mathrm{~cm}$;

4 Surface topography should be relatively flat, to avoid the effect of lateral redistribution of soil;

5 Soil sampling should be performed at least 3 years after deforestation. If several ages were sampled for a specific forest-agroecosystem comparison, we chose the oldest sampling date and discarded the other sampling dates to avoid an over-representation of studies where soil were frequently sampled over time. Some studies were carried out on the same experimental site, for instance the pastures of Fazenda Nova Vida, in Rôndonia (Brazil) (de Moraes et al., 1996; Neill et al., 1997; Cerri et al., 2003, 2004; Lisboa et al., 2009). For this experiment, we selected the data from Neill et al. (1997) because other more recent studies were dealing with a sampling depth of $20 \mathrm{~cm}$, whereas Neill et al. (1997) sampled soils down to $30 \mathrm{~cm}$ depth.

Additional data were compiled: the soil type, clay content when mentioned, mean annual precipitation (MAP) when mentioned and indications on management practices. For sites where MAP was lacking, we used the WMO data (World Meteorological Organization; http://www.agteca.com/Projects/Climate/) and chose the data from the nearest station from the site.

\section{The database}

We listed 21 studies made since 1976 meeting our criteria, located over 52 sites in the Amazon biome, of which 49 were located in the Brazilian Amazon (Table 2). This dataset included 70 forest-agroecosystem comparisons, of which 52 are forest-pasture comparisons and 18 are forest-annual crop comparisons. There were 4 comparisons with other types of agroecosystems such as fallows or mixed crop/pasture systems, which were not analysed here because they were too poorly represented. Until the mid-2000s, pastures were the most studied system; in the late 2000s, a noteworthy number of forest-cropland comparisons have been published, particularly from the work of Maia et al. (2010) in south-western Amazonia. Pastures were exclusively grazed by cattle except the one studied by Perrin et al. (2014) that was mowed. Annual crops were mainly corn, soybean, cassava and rice. In the majority of compiled studies, deforestation used burning after manual or mechanized cutting of the vegetation. In
Davidson et al. (2008) and Perrin et al. (2014), the sites were deforested without using fire.

Among the 20 studies compiled in this paper, 18 studies were chronosequences (synchronic approach), that is carbon stocks were measured in an agroecosystem whose age was known, and compared to a reference state (here the forest), assuming that the initial conditions (nature and properties of soils) were similar for the forest and the paired agroecosystem. Three studies used a diachronic approach, where stocks were measured on different dates in a single site, before and after deforestation: Janssen \& Wienk (1990) in Surinam, Davidson et al. (2008) in Pará (Brazil) and Perrin et al. (2014) in French Guiana.

Soils of compiled studies were mainly Ferralsols $(n=33$ sites) and/or Acrisols $(n=14)$. Few comparisons concerned soils less present in Amazonia: Maia et al. (2009) studied two sites in Mato Grosso where soils had high-activity clays and Melo (2003) studied Lixisols/Luvisols in Acre.

\section{Management practices}

For pastures and croplands, we analysed management factors recorded in our dataset.

For pastures, many classifications of management types have been proposed. We used the classification of Maia et al. (2009): the pasture was considered as (i) degraded in the case of drastic decrease in grass productivity due to overgrazing, invasion by weeds, and/or soil erosion; (ii) nominal for pastures with moderate grazing pressure $\left(<1.5\right.$ cattle ha $\left.^{-1}\right)$ inducing a reasonable grass productivity, but not fertilized or limed; and (iii) improved if grazing pressure was moderate, and improved by fertilization, liming or planting of productive grasses. Pastures characterized as 'well managed' in Cerri et al. (2007) were considered by Maia et al. (2009) as 'nominal' as they were not fertilized. It was sometimes difficult to establish the class of pasture management from the information provided in the papers. Moreover, in the chronosequence approach, the uncertainty of knowledge about agroecosystem management is high. For pastures, we did not analyse the effect of grass species on SOC dynamics as Neill \& Davidson (2000) did, because this information was not always available. In addition, in some chronosequences, grasses differed depending on the age of sampled plots (Koutika et al., 1997) or several species were present in the same plot (Cerri et al., 2007).

For croplands, the only management practice that was mostly but not always mentioned was soil tillage.

\section{$\delta^{13} \mathrm{C}$ data in Amazonian pastures}

Experiments on forest conversion to pasture allow the use of isotope labelling by natural $\delta^{13} \mathrm{C}$ because of the transition from C3-type vegetation (all tree species) to C4-type vegetation (pasture grasses) (Cerri et al., 1985; Balesdent et al., 1988). Thus, it is possible to distinguish over time the soil carbon proportions derived from forest and from pasture. This requires the determination of the isotopic ratios of $\delta^{13} \mathrm{C}$ in several types of sample: the soil under forest, the soil under 
Table 2 Amazonian data analysed

\begin{tabular}{|c|c|c|c|c|c|c|c|c|c|c|}
\hline Localization & $\begin{array}{l}\text { Land } \\
\text { use }\end{array}$ & $\begin{array}{l}\text { Sampling } \\
\text { depth } \\
(\mathrm{cm})\end{array}$ & $n$ sites & $\begin{array}{l}n \text { comp. } \\
\dagger\end{array}$ & $\begin{array}{l}\text { Max. } \\
\text { age }(y r) \ddagger\end{array}$ & $\begin{array}{l}n \text { smp. } \\
\text { Fo. } \S\end{array}$ & $\begin{array}{l}n \text { smp. } \\
\text { Agro. } \S\end{array}$ & $\operatorname{SOC} \uparrow$ & $\begin{array}{l}\text { Error } \\
* *\end{array}$ & Reference \\
\hline Pará* & $\mathrm{Pa}$ & 20 & 2 & 2 & 11 & & & & & Falesi (1976) \\
\hline Suriname & $\mathrm{Cr}$ & 20 & 1 & 3 & 12 & 10 & 5 & Rep. & & Janssen \& Wienk (1990) \\
\hline Amazonas* & $\mathrm{Pa}$ & 20 & 1 & 1 & 8 & 3 & 2 & Rep. & & Cerri et al. (1991) \\
\hline Pará* & $\mathrm{Pa}$ & 40 & 1 & 1 & 10 & 1 & 1 & & & Desjardins et al. (1994) \\
\hline Pará* & $\mathrm{Pa}$ & 100 & 1 & 2 & 23 & 8 & 8 & Comp. & & Trumbore et al. (1995) \\
\hline Pará* & $\mathrm{Pa}$ & 100 & 1 & 1 & 17 & 4 & 4 & Comp. & & Koutika et al. (1997) \\
\hline Rondônia* & $\mathrm{Pa}$ & 30 & 7 & 7 & 81 & $4-5$ & $4-5$ & Rep. & $x$ & Neill et al. (1997) \\
\hline Pará* & $\mathrm{Cr} \mathrm{Fa}$ & 40 & 1 & 2 & 10 & 10 & 5 & Rep. & $x$ & Fujisaka et al. (1998) \\
\hline Pará* & $\mathrm{Pa}$ & 20 & 1 & 1 & 15 & 3 & 3 & Rep. & $X$ & Bernoux et al. (1999) \\
\hline Acre* & $\mathrm{Pa}$ & 100 & 1 & 1 & 20 & 6 & 6 & Rep. & $X$ & Melo (2003) \\
\hline $\begin{array}{l}\text { Pará and } \\
\text { Amazonas* }\end{array}$ & $\mathrm{Pa}$ & 20 & 2 & 2 & 15 & 10 & 10 & Comp. & & Desjardins et al. (2004) \\
\hline Pará* & $\mathrm{Pa}$ & 20 & 4 & 4 & 31 & 4 & $1-4$ & Rep. & & Cerri et al. (2007) \\
\hline Pará* & $\mathrm{Cr} \mathrm{Fa}$ & 30 & 1 & 3 & 3 & 2 & 2 & Rep. & $x$ & Davidson et al. (2008) \\
\hline Acre* & $\mathrm{Pa}$ & 95 & 1 & 1 & 12 & 3 & 3 & Rep. & & Salimon et al. (2009) \\
\hline $\begin{array}{l}\text { Mato Grosso } \\
\text { \& Rondônia* }\end{array}$ & $\mathrm{Pa}$ & 30 & 13 & 18 & 29 & 5 & 5 & Rep. & & Maia et al. (2009) \\
\hline $\begin{array}{l}\text { Mato Grosso } \\
\text { \& Rondônia* }\end{array}$ & $\mathrm{Cr} \mathrm{Pa}$ & 30 & 8 & 8 & 26 & 5 & 5 & Rep. & & Maia et al. (2010) \\
\hline $\begin{array}{l}\text { Mato Grosso } \\
\text { \& Rondônia* }\end{array}$ & Cr Pa Mix & 30 & 2 & 6 & 15 & 5 & 5 & Rep. & & Carvalho et al. (2010) \\
\hline Colombia & $\mathrm{Pa}$ & 100 & 1 & 5 & 53 & 16 & 16 & Rep & $x$ & Mosquera et al. (2012) \\
\hline Pará* & $\mathrm{Pa}$ & 20 & 1 & 1 & 15 & 4 & 4 & Comp. & & Souza Braz et al. (2013) \\
\hline Pará* & $\mathrm{Pa}$ & 30 & 1 & 1 & 55 & 5 & 5 & Rep. & $x$ & Frazão et al. (2013) \\
\hline French Guiana & $\mathrm{Cr} \mathrm{Pa}$ & 30 & 1 & 3 & 3 & 17 & 24 & Rep. & $x$ & Perrin et al. (2014) \\
\hline
\end{tabular}

For land use, Pa, pastures; $\mathrm{Cr}$, croplands; Fa, fallows; Mix, mixed pastures/croplands.

*Brazilian state.

$\dagger$ Number of comparisons forest-agroecosystem.

$\$$ Age of the oldest agroecosystem.

$\S$ Number of soil samples collected in forest and agroecosystem.

ףSOC stock assessment (Rep. = use of replication, Comp. = analysis of composite samples).

${ }^{* *}$ Mention of error on SOC stock $(X=$ yes $)$.

pasture, and vegetation or litter of the two systems (Bernoux et al., 1998). These isotopic methods were used in 16 chronosequences in Amazonia with a total of 39 sampling points in pastures, in 0-20 or 0-30 cm layers. These data were compiled and analysed to establish trends in the mineralization of forest-derived carbon and its substitution by pasture-derived carbon. The effect of pasture management on the dynamics of forest and pasture carbon pools could not be analysed because among the 16 chronosequences, 14 included nominal pastures, and degraded pastures were not represented. The proportions of carbon derived from pasture and forest were not calculated for each study because all the raw data were not always available. Thus, the quantities of SOC derived from forest and pasture were extracted from papers as SOC proportions or absolute SOC stock. For the forest-derived SOC (named C3SOC), the percentage of C3-SOC for each date was expressed in two ways: in relation to the SOC stock which was measured at time $\mathrm{t}(\mathrm{C} 3 \mathrm{tx})$ and in relation to initial SOC stock of forest (C3t0). In contrast, for pasture-derived SOC (named C4-SOC), its accumulation over time was expressed as absolute SOC stock $\left(\mathrm{Mg} \mathrm{C} \mathrm{ha}^{-1}\right)$.

\section{Statistical analysis}

The change in SOC stock after deforestation was expressed in $\mathrm{Mg} \mathrm{C} \mathrm{ha}{ }^{-1}$ ( $\mathrm{SOC}_{\text {agroecosystem }}-\mathrm{SOC}_{\text {forest }}$ ) and in \% ([SOC agroecosystem - soCforest $\left.] / \mathrm{SOC}_{\text {forest }}\right)$. We modelled the SOC change (\%) separately for pastures $(n=52)$ and croplands $(n=18)$ with multiple linear regressions models, taking as independent variables the age of the agroecosystem, the MAP and the initial SOC stock under forest. The number of dry months and the clay content of soils were not included in the analysis because these parameters were too rarely recorded in the compiled studies. At the biome scale, annual temperature varies little (Nobre et al., 2009) so it was not included in the analysis. We analysed isotopic data in pastures (C3t0-SOC and C4-SOC variations, $n=16$ chronosequences) with the same manner, but soil clay content could be added to tested parameters as it 
was mentioned in all studies dealing with isotopic data. Nonlinear regression was applied to the evolution of C3tx-SOC, C3t0-SOC and C4-SOC in pastures over time, including all the sampling points $(n=39)$. We compared the effect of pasture management (degraded/nominal/improved) on SOC stock changes after deforestation with nonparametric test of Kruskal-Wallis, as data were non-normal. Statistical analyses were performed with SigmaPlot version $11.0^{\circledR}$ for multiple linear and nonlinear regressions, and with $\mathrm{R}$ version 2.15.2 for Kruskal-Wallis test.

\section{Results}

\section{General trends of SOC stock changes after deforestation}

On average, SOC stocks decreased by $8.5 \pm 2.9 \%$ for annual crops and increased by $6.8 \pm 3.1 \%$ for pastures after deforestation, these values being significantly different from 0 at $P<0.05$ (Table 3 ). This represents an absolute loss of $4.5 \mathrm{Mg} \mathrm{C} \mathrm{ha}{ }^{-1}$ for croplands (age of deforestation ranging from 3 to 19 years) and a gain of 2.2 $\mathrm{Mg} \mathrm{C} \mathrm{ha}{ }^{-1}$ for pastures (age of deforestation ranging from 3 to 81 years) in the $0-20 / 30 \mathrm{~cm}$ layer compared to forest. Pastures had more variable responses than croplands. The mean age of the compiled chronosequences was higher for pastures (17.6 years compared to 8.7 years for croplands).

\section{Effect of soil and climatic factors}

Analysis of soil and climatic variables (precipitation, forest SOC stock), which was performed for pastures and croplands, shows that these parameters did not influence the dynamics of SOC after deforestation. Multiple linear regressions using soil and climatic variables failed for croplands. For pastures, the time since deforestation was a significant factor in the regression

Table 3 Soil organic carbon stock under forest and agroecosystems, and SOC stock changes after deforestation in Amazonia. Means are followed by standard error. For absolute SOC stocks, $n=18$ for croplands and $n=45$ for pastures. For SOC stock changes, $n=18$ for croplands and $n=52$ for pastures

\begin{tabular}{lcc}
\hline & Forest-Croplands & Forest-Pastures \\
\hline Mean SOC stock, layer $0-20 / 30 \mathrm{~cm}\left(\mathrm{Mg} \mathrm{ha}^{-1}\right)$ & \\
Forest & $47.5 \pm 3.4$ & $40.5 \pm 2.3$ \\
Agroecosystem & $43.0 \pm 3.0$ & $42.7 \pm 2.4$ \\
SOC stock change, all layers $(\%)$ & \\
Mean & $-8.5 \pm 2.9$ & $+6.8 \pm 3.1$ \\
$P$ value $t$-test & 0.006 & 0.016 \\
Minimum & -32.5 & -48.7 \\
1st quartile & -17.9 & -10.6 \\
3rd quartile & -5.1 & 21.2 \\
Maximum & +15.5 & +54.8 \\
Age (years) & $8.7 \pm 1.2$ & $17.6 \pm 2.8$ \\
\hline
\end{tabular}

$(P=0.002)$, but not the other parameters, and the adjusted $R^{2}$ for the resulting model was only 0.17 (Table 4). The correlation matrices led to the same conclusions (data not shown). Losses or gains of SOC in pastures were not related to mean annual precipitation (MAP), despite a wide range of precipitation across our dataset (between 1500 and $3750 \mathrm{~mm}$ ) (Fig. 1a).

\section{Effect of agroecosystem management}

For pastures, the classification of management classes as degraded/nominal/improved led to the following results: on average, SOC stock did not change in degraded pastures $(-0.5 \pm 7.3 \%, n=15)$ and increased by $9.8 \pm 4.3 \% \quad(n=23)$ and $11.9 \pm 4.0 \% \quad(n=12)$ in nominal and improved pastures (Fig. 2). But we did not observe any significant difference in the mean SOC changes between management classes with KruskalWallis test $(P=0.252)$, and the three management classes included situations where stocks increased and decreased (Fig. 2). Across our dataset, the degraded pastures response to SOC change had the widest dispersion.

For croplands, it was difficult to explain SOC variations due to soil tillage after deforestation. In 14 of 18 comparisons, SOC stocks decreased after deforestation, but this trend was found for both agricultural practices (with and without tillage) (Fig. 3). However, after deforestation, SOC stocks never increased in systems where the soil was tilled, at least with the croplands of our dataset.

\section{$\delta^{13} \mathrm{C}$ data in pastures}

After deforestation, C3-SOC dynamics expressed in relation to the total SOC stock at time $t$ was charac-

Table 4 Multiple linear regressions of SOC stock changes $(\%)$ in pastures $(n=52)$ and croplands $(n=18)$ after deforestation (sampling depth from $20 \mathrm{~cm}$ to $100 \mathrm{~cm}$ ). Parameters are time since conversion (age), SOC stock found in forest $\left(\mathrm{SOC}_{\mathrm{Fo}}\right.$ ) and mean annual precipitation (MAP). Values are followed by standard errors

\begin{tabular}{llcl}
\hline SOC change & Parameter & Values & $P$ value \\
\hline Pasture (\%) & Intercept & $-20.3 \pm 12.4$ & 0.11 \\
& Age (years) & $0.80 \pm 0.23$ & 0.002 \\
& SOC $_{\mathrm{Fo}}\left(\mathrm{Mg} \mathrm{ha}{ }^{-1}\right)$ & $0.12 \pm 0.18$ & 0.49 \\
& MAP (mm) & $0.003 \pm 0.007$ & 0.66 \\
& $R^{2}$ adjusted & 0.17 & \\
Croplands (\%) & Intercept & $-5.4 \pm 25.4$ & 0.83 \\
& MAP (mm) & $0.005 \pm 0.01$ & 0.63 \\
& Age (years) & $-0.39 \pm 0.55$ & 0.49 \\
& SOC $_{\mathrm{Fo}}\left(\mathrm{t} \mathrm{ha}^{-1}\right.$ ) & $-0.22 \pm 0.22$ & 0.34 \\
& $R^{2}$ adjusted & 0 & \\
\hline
\end{tabular}



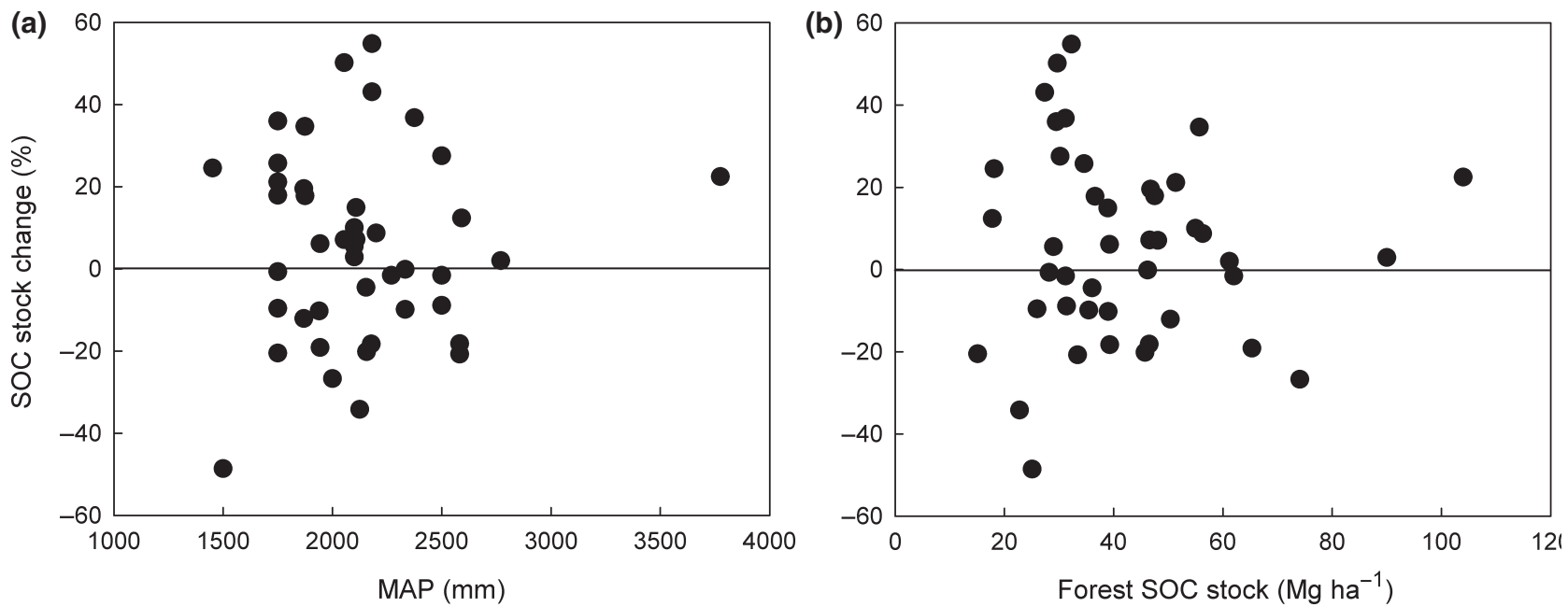

Fig. 1 Effect of MAP (mean annual precipitation) (panel a) and SOC stock under forest (panel b) on the SOC stock change after deforestation and pasture establishment $(n=43$, all layers considered). For sites where one forest soil is compared to several pastures (e.g. Mosquera et al., 2012), we considered the mean of the SOC stock change.

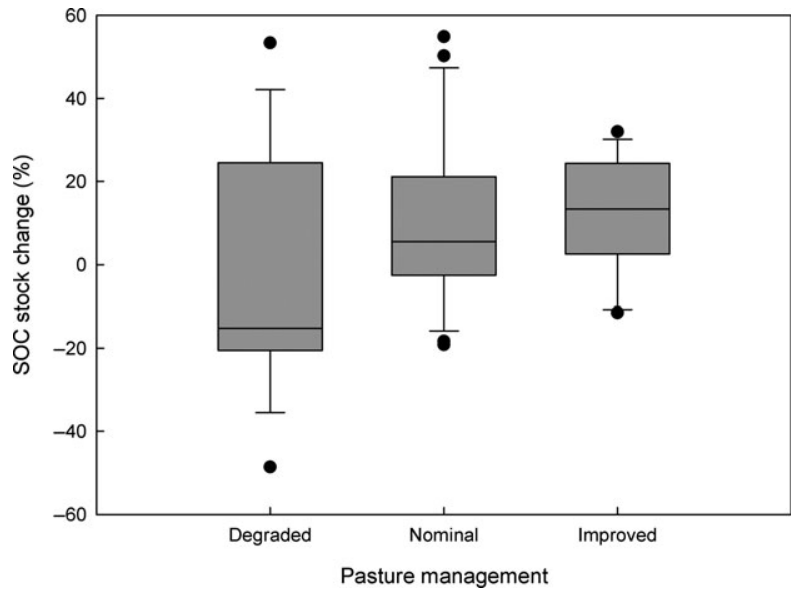

Fig. 2 Pasture management effect on the SOC stock after deforestation ( $n=15$ for degraded, 23 for nominal and 12 for improved pastures). Box plots display the median, interquartile range, 10-90 percentile (whiskers) and outliers (circles). Pastures studied by Fujisaka et al. (1998) and Frazão et al. (2013) were not considered here because no information about pasture management was provided in their study.

terized, as expected, by a decrease over time (Fig. 4). This decrease could be fitted to a first-order exponential decay model, $\mathrm{y}=$ Yo exp $(-\mathrm{kt})$ with $\mathrm{k}=0.0267\left(R^{2}=0.29 ; n=39\right)$, that is a half-life of 26 years. However, if the dynamics of the C3-SOC is expressed relative to the initial SOC stock in forest (the latter is here assumed to be $100 \%$ derived from C3 plants), points do not show a clear trend, and it was impossible to fit a decay function (Fig. 5a). In some fields, the C3-SOC stock was even higher than the initial stock measured under forest.

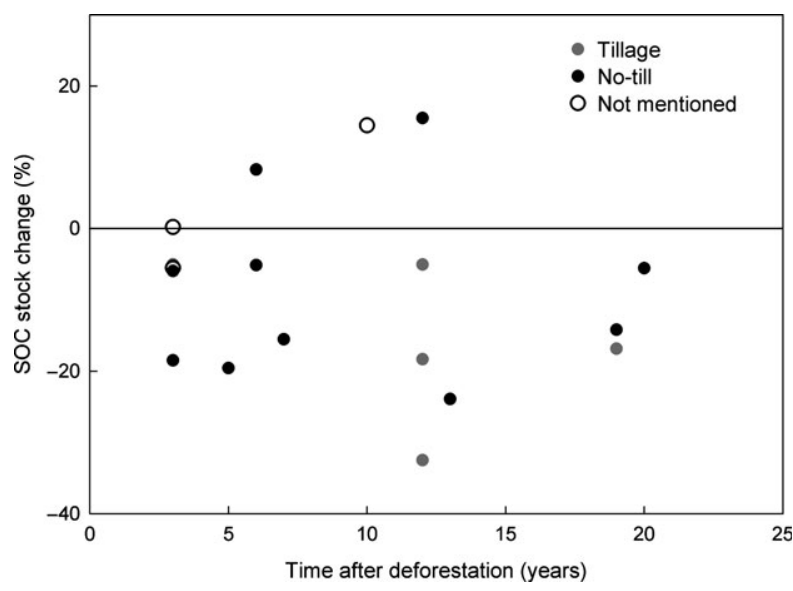

Fig. 3 Soil tillage effect on SOC stock changes after deforestation and cropland establishment.

On the other hand, the accumulation of C4-SOC, expressed in $\mathrm{Mg} \mathrm{ha}{ }^{-1}$, was better organized (Fig. 5b). An accumulation model with a maximum was fitted and resulted in a plateau at $19.9 \mathrm{Mg} \mathrm{C}$ ha ${ }^{-1}$, which is reached after twenty years $\left(R^{2}=\right.$ $0.40)$.

The analysis of the effect of soil and climatic variables on the dynamics of C3-SOC and C4-SOC was inconclusive (Table 5). The percentage of C3t0 carbon cannot be explained by any of the factors tested. On the other hand, the C4-SOC accumulation is positively correlated with the age of the chronosequence, and the accumulation of C4-SOC in pasture was positively correlated $(P=0.004)$ with the SOC stock in the preceding forest (Table 5). 


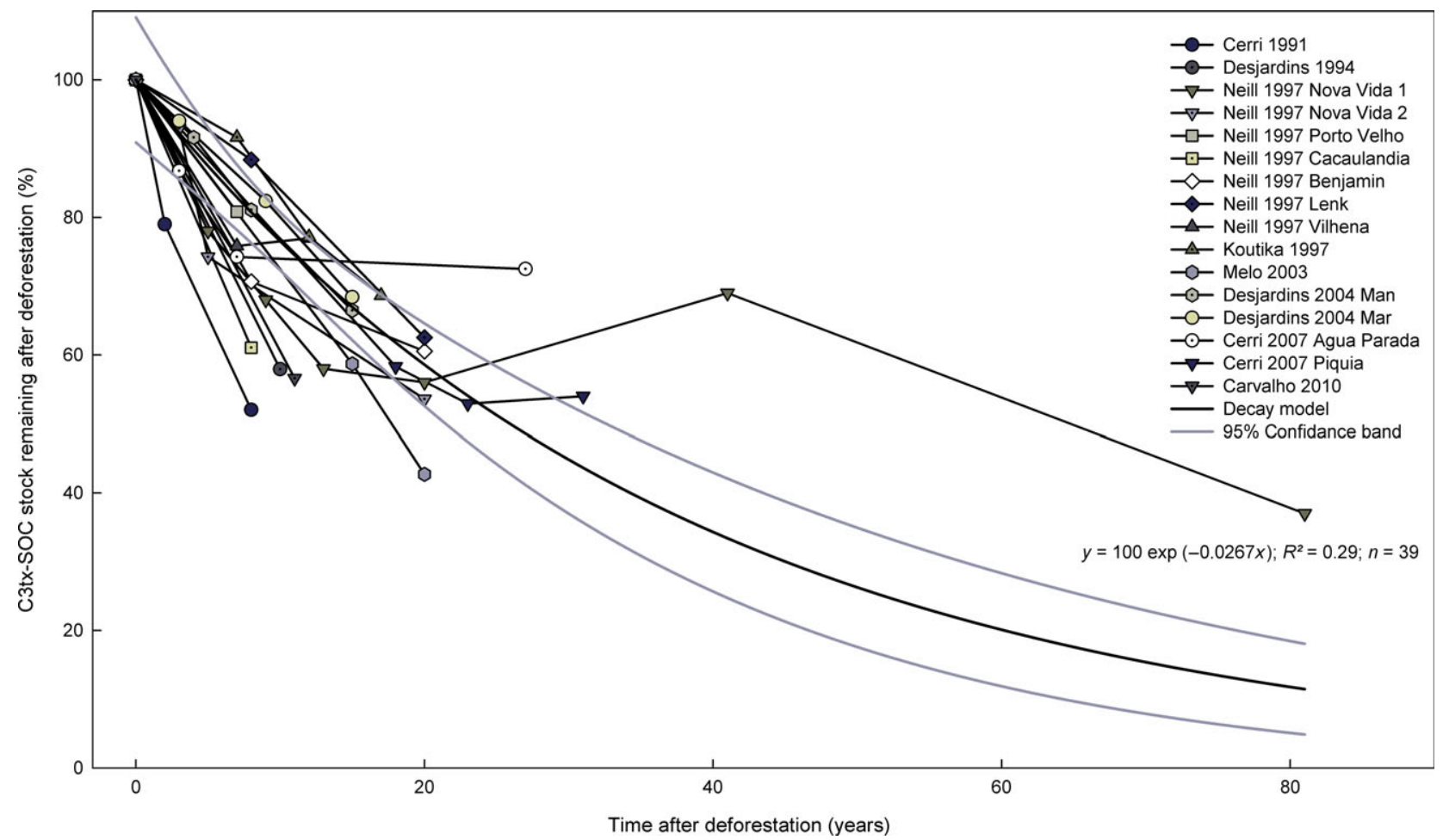

Fig. 4 Decay of soil carbon derived from forest (C3tx-SOC) in Amazonian pastures (layer 0-20/30 cm).

\section{Discussion}

\section{SOC stock changes: general trends}

The average decrease of SOC stocks in Amazonian croplands was surprisingly lower than in results of meta-analyses conducted in the world across all climates (Guo \& Gifford, 2002; Murty et al., 2002) or in the tropics (Don et al., 2011) (Table 1). The age of the considered systems could explain these differences: for example, Don et al. (2011) found a SOC loss of 32\% in humid tropics, but the average age of croplands was 28 years. Besides, the default emission factor established by IPCC for a land-use change from forest to cropland in humid tropics is a SOC loss of $42 \%$ in the 0-30 cm layer after more than 20 years (Penman et al., 2003). Although the SOC decrease rates were higher in the early years after deforestation (Davidson \& Ackerman, 1993), it is likely that the carbon cycle was not in a steady state situation eight years after deforestation (the average age in our dataset), which would explain the relatively small decrease in the observed SOC.

For pastures, the Amazonian trend here $(+6.8 \pm 3.1 \%$ of SOC stock) was close to that observed for the world as a whole by Guo \& Gifford (2002) (+8\%). However, our results are far from those of Don et al. (2011), who observed a decrease in SOC stocks in the tropics of
$12.1 \%$, and those of Murty et al. (2002), who found no significant difference in SOC stocks after deforestation and pasture establishment.

These opposing trends between croplands and pastures can be explained by the lower carbon restitutions in cropland systems compared to natural forests (Lal et al., 1997) and by loss of protection of forest carbon during cultivation (Mann, 1986; Feller \& Beare, 1997). On the other hand, the storage of SOC in pastures is favoured by the large root activity of grasses, which provides enough carbon to offset the carbon mineralization of native forest carbon (Fisher et al., 1994).

\section{Soil and climatic factors}

Despite strong gradients of MAP, clay content and SOC stocks under forest, none of these factors could explain the trajectory of SOC stocks after deforestation in Amazonia. This contrasts in many ways with the existing literature. In the Amazon, Neill \& Davidson (2000) showed that the SOC stock variation in pastures was negatively correlated to the SOC stock found in forest. These findings are also shared by Holmes et al. (2006). But Neill \& Davidson (2000) included sites deforested less than 2 years earlier (Cerri et al., 1991; Luizão et al., 1992) and expressed their results of SOC changes in \% $\mathrm{yr}^{-1}$, thus the SOC change rates could be high in these 

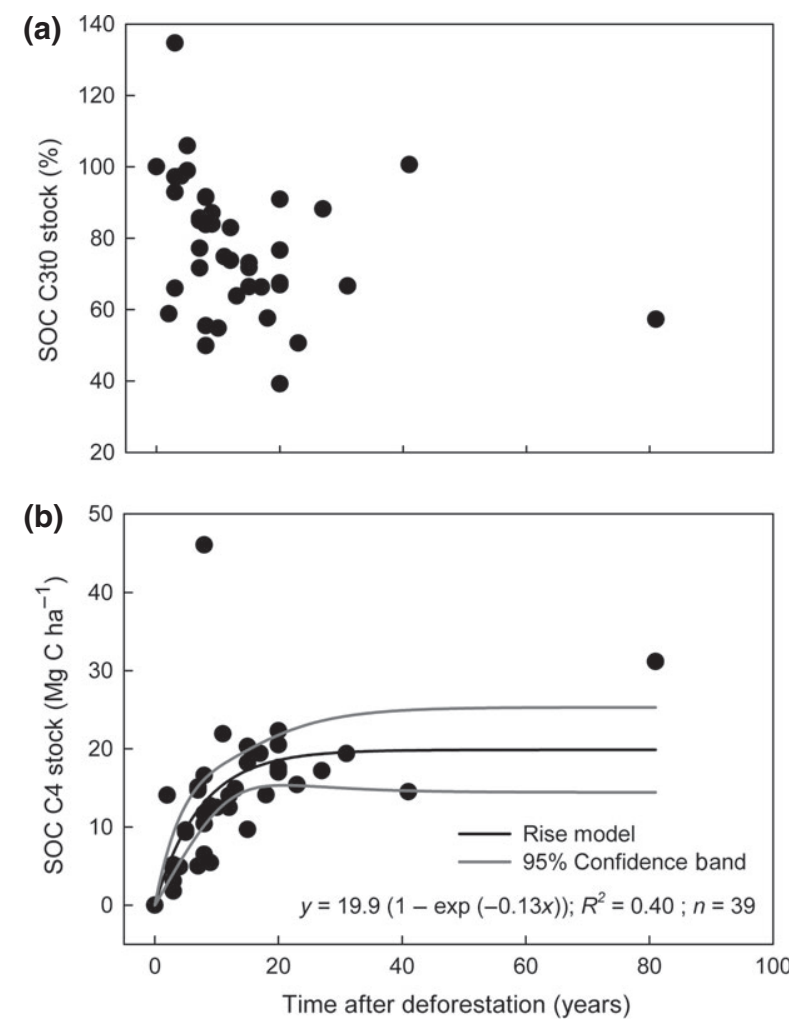

Fig. 5 Decay of soil carbon derived from forest (C3t0-SOC) (panel a) and accumulation of soil carbon derived from pasture (C4-SOC) (panel b) in Amazonian pastures (layer 0-20/30 cm).

Table 5 Multiple linear regressions of C3t0-SOC and C4SOC trend in pastures after deforestation in the layer 0-20/ $30 \mathrm{~cm}(n=16)$. Parameters are soil clay content (clay), time since conversion (age), SOC stock found in forest $\left(\mathrm{SOC}_{\mathrm{Fo}}\right.$ ) and mean annual precipitation (MAP)

\begin{tabular}{|c|c|c|c|}
\hline SOC change & Parameter & Values & $P$ value \\
\hline \multirow[t]{6}{*}{$\mathrm{C} 3 \mathrm{t} 0-\mathrm{SOC}(\%)$} & Intercept & $94.0 \pm 45.6$ & 0.064 \\
\hline & Clay (\%) & $0.23 \pm 0.22$ & 0.33 \\
\hline & $\mathrm{MAP}(\mathrm{mm})$ & $-0.01 \pm 0.02$ & 0.70 \\
\hline & Age (years) & $-0.12 \pm 0.24$ & 0.63 \\
\hline & $\operatorname{SOC}_{\mathrm{Fo}}\left(\mathrm{t} \mathrm{ha}^{-1}\right)$ & $-0.36 \pm 0.39$ & 0.38 \\
\hline & $R^{2}$ adjusted & 0 & \\
\hline \multirow[t]{6}{*}{ C4-SOC $\left(\mathrm{Mg} \mathrm{ha}^{-1}\right)$} & Intercept & $10.0 \pm 20.6$ & 0.638 \\
\hline & Clay (\%) & $-0.20 \pm 0.10$ & 0.083 \\
\hline & $\mathrm{MAP}(\mathrm{mm})$ & $-0.01 \pm 0.01$ & 0.452 \\
\hline & Age (years) & $0.27 \pm 0.11$ & 0.031 \\
\hline & $\operatorname{SOC}_{\mathrm{Fo}}\left(\mathrm{t} \mathrm{ha}^{-1}\right)$ & $0.65 \pm 0.18$ & 0.004 \\
\hline & $R^{2}$ adjusted & 0.47 & \\
\hline
\end{tabular}

destabilized young systems. With our larger database and expressing SOC changes in \%, we did not observe this kind of correlation (Fig. 1b). This absence of correlation between the SOC stock in forest and the change in SOC stock in following pasture is in agreement with

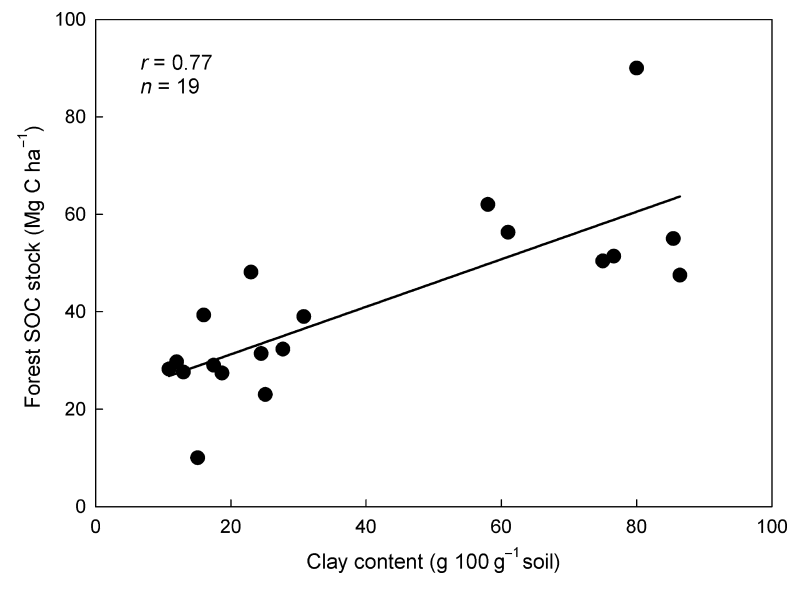

Fig. 6 Relationship between SOC stock under forest and soil clay content in our Amazonian dataset (layer 0-20/30 cm).

several studies that showed no effect of clay in SOC dynamics after deforestation (Davidson \& Ackerman, 1993; Don et al., 2011). Indeed, it can be assumed that sites with high clay contents under forest had high SOC stocks (Fig. 6), but this parameter did not affect the SOC dynamics in established pastures, at least on this timescale.

As mentioned earlier, the literature on the effect of mean annual precipitation (MAP) on SOC stock change is contradictory. In a meta-analysis including precipitation between 1400 and $2300 \mathrm{~mm}$, Eclesia et al. (2012) assumed that primary productivity in pastures increased with precipitation, explaining the correlation they found between SOC variation in pastures and MAP. Guo \& Gifford (2002) showed that beyond MAP of $3000 \mathrm{~mm}$, SOC stocks decreased in pastures, presumably due to the greater water erosion (Alegre \& Cassel, 1996) that would export SOC out of plots. Other meta-analyses conducted on continental or global scales showed that these soil and climatic factors could influence the dynamics of SOC. However, the analyses can be contradictory if the spatial scale is changed, and processes that explain the role of soil and climatic factors are not clearly explained, especially in the humid tropics. Therefore, the analysis of agroecosystem management appears relevant to evaluate the fate of SOC after deforestation in Amazonia.

\section{Agroecosystem management}

For pastures, our results contrast with the findings of Fearnside \& Barbosa (1998), who suggested that pastures with 'typical' management lost SOC (17.8\%), whereas pastures with an 'ideal' management gained SOC (15.0\%). But their 'typical' pastures did not always correspond to the degraded pastures defined by Maia 
et al. (2009) (e.g. the pasture studied by Desjardins et al. (1994) was slightly fertilized but considered by Fearnside \& Barbosa as 'typical'). The wide dispersion of SOC change in degraded pastures (Fig. 2) can be explained by the diversity of situations where the productivity of forage grass decreased. On the one hand, if the pasture was overgrazed and/or suffered severe water erosion, it is likely that the SOC stock would decrease due to reduced SOC input and/or because of SOC loss by erosion. On the other hand, pastures invaded by weeds or affected by woody encroachment can store SOC through above-ground and belowground plant biomass inputs, which are not exported by livestock. Finally, the assessment of pasture degradation is based here on agronomic criteria, which do not always allow a suitable assessment of the carbon cycle of the soil. Curiously, the maximum SOC gains were lower in improved pastures than in nominal or degraded pastures. It is possible that fertilization of pastures increases SOC mineralization and thus leads to a fall in SOC stock. However, on four of the sets of improved pastures, SOC stock was measured down to $100 \mathrm{~cm}$ depth (Mosquera et al., 2012) which may underestimate the gains of SOC compared to sampling down to 20 or $30 \mathrm{~cm}$ depth.

\section{Forest-derived and pasture-derived SOC dynamics}

At this stage, the isotopic data do not suggest new explanations for the SOC dynamics after deforestation: we observed a high heterogeneity of the carbon derived from forest at the biome scale. The interpretation must lie in the soil or climate, as the management of all the pastures was similar. Nevertheless, the accumulation of carbon derived from grasses appeared relatively consistent with time, that is an accumulation with a maximum of $20 \mathrm{Mg}$ SOC ha ${ }^{-1}$ (Fig. 5b). The positive relationship between C4-SOC accumulation and pasture age is not surprising given the young age of the sampled pastures, whose soil carbon cycle did not reach an equilibrium level. The correlation between $\mathrm{C4}$ SOC accumulation and SOC stock in forest is more surprising, but could be explained by the fact that high SOC stocks observed under forests are related to soil and climatic variables which contribute to maintain a high primary productivity. This assumption cannot be verified with our dataset. However, the clay content of soil and MAP did not influence the accumulation of C4-SOC, and we have seen that the total SOC stock changes in pastures were not dependent on the SOC stocks under the reference forest.

The decrease in the carbon derived from forest, expressed in relation to the initial carbon stock, was very variable, which may be due to the disturbance of the ${ }^{13} \mathrm{C}$ signal by the input of carbon C3 derived from decomposing stumps, saplings and weeds (Camargo et al., 1999; Powers \& Veldkamp, 2005). The great variation in the C3-SOC trend in the pastures could be also related to the $\mathrm{C} 4$ inputs to pastures, derived from litterfall but also from root activity (Camargo et al., 1999). Thus, rhizodeposition could promote a priming effect of native soil carbon (Paterson, 2003), but with a wide magnitude according to the sites (Cheng et al., 2014), explaining high variability of the C3-SOC trend.

\section{Sources of error and uncertainties}

Data heterogeneity is a major problem in the metaanalyses, especially as the studies reviewed here were made over a long period of time (several decades). Our selection was wide to maintain representativeness of trends at the biome scale. We analysed SOC stock variations assessed at 20 or $30 \mathrm{~cm}$ depth in the same way: this difference of sampling depth could account for some of the variability in the SOC response. At this point, it is necessary to stress that the IPCC recommends comparing the stocks to $30 \mathrm{~cm}$ depth (Penman et al., 2003), we discuss this point later. We deliberately did not select studies according to the sampling strategy or degree of replication of the experiment, because this would have obliged us to exclude many of the studies. Not all the studies presented uncertainty on SOC stock values, although it is essential to evaluate differences in land use.

A major source of uncertainty in our review is the fact that forests and agroecosystems were mainly compared using the chronosequence approach; only three studies were diachronic. In chronosequence studies, soil properties under forest and under pastures could be slightly different, thus increasing the uncertainty associated with SOC dynamics after deforestation. For example, Frazão et al. (2013) reported a difference of $8 \%$ in the clay contents between the soil under forest and pasture; the authors corrected the stocks under pastures using the method established by de Moraes et al. (1996), assuming that SOC stocks were correlated with the clay content (Feller et al., 1991). We believe that this correction can be made if the relationship between SOC stock under natural vegetation and soil clay content is established on a consistent soil unit at local scale. If not, this correction could be risky because de Moraes et al. (1996) based their assumption on a relationship between SOC and clay content found at the global scale (Feller et al., 1991). In our dataset, we observed a correlation between SOC stocks and clay content (Fig. 6), but it is based on two extreme clusters with no intermediate values and therefore might not apply to studies of a different scale. 
For Cerrado savannahs, Costa Junior et al. (2013) showed that the chronosequence approach overestimated the carbon storage after land-use change and appeared less accurate than the diachronic approach. For these authors, the variability of soil properties (including clay content) and the management history after deforestation explained the differences found between the two approaches. The efficiency of vegetation burning, the stumps remaining in the soil, cultivation practices before pasture establishment and the frequency of fires in pastures are factors that contribute to the variability of SOC response on a local scale, but also at the biome scale. Finally, human practices induce heterogeneities in the SOC response after land-use change, which are added to the natural heterogeneity of soil properties occurring at local (Do Nascimento et al., 2004) and global scale (Quesada et al., 2011).

For isotopic data, some considerations have to be added to the uncertainties presented previously; in particular, the uncertainty associated with the calculation of the proportions of carbon derived from forest and pasture. These proportions are calculated from Eqns (1) and (2) adapted from Bernoux et al. (1998):

$$
\begin{gathered}
\mathrm{Cp}=\mathrm{Ct} \times(\delta t-\delta \text { ref }) /(\delta P-\delta F) \\
\mathrm{Cf}=\mathrm{Ct}-\mathrm{Cp}
\end{gathered}
$$

where $\mathrm{Cp}$ is the quantity of carbon derived from pasture, $\mathrm{Cf}$ the quantity of carbon derived from forest, $\mathrm{Ct}$ the quantity of total soil carbon, $\delta \mathrm{t}$ the $\delta^{13} \mathrm{C}$ value of the soil under pasture, $\delta$ ref the $\delta^{13} \mathrm{C}$ value of the soil under forest at the same depth, $\delta \mathrm{P}$ the $\delta^{13} \mathrm{C}$ value of the pasture vegetation or litter, and $\delta \mathrm{F}$ the $\delta^{13} \mathrm{C}$ value of the forest vegetation or litter. In the compiled studies, we observed that for Eqn (1) although $\delta \mathrm{F}$ did not vary significantly (only from -28 to $-29 \%$ ), the $\delta \mathrm{P}$ values were widely dispersed. The different grasses used in pastures have different $\delta^{13} \mathrm{C}$ values, but these can also vary according to the type of sample analysed. These variations give a difference of up to $4 \%$ in the $\delta^{13} \mathrm{Cp}$ values (Table 6). The uncertainty in this value implies a

\begin{tabular}{|c|c|c|c|}
\hline Grass species & Sample & $\delta^{13} \mathrm{C}(\%)$ & Reference \\
\hline $\begin{array}{l}\text { Pennisetum } \\
\text { purpureum }\end{array}$ & $\begin{array}{l}\text { Leaves } \\
\text { Roots }\end{array}$ & $\begin{array}{l}-11,20 \\
-13,00\end{array}$ & $\begin{array}{l}\text { Desjardins } \\
\text { et al. (1994) }\end{array}$ \\
\hline $\begin{array}{l}\text { Urochloa brizantha } \\
\text { Panicum maximum }\end{array}$ & $\begin{array}{l}\text { Litter } \\
\text { Litter }\end{array}$ & $\begin{array}{l}-14,30 \\
-15,49\end{array}$ & $\begin{array}{l}\text { de Moraes } \\
\text { et al. (1996) } \\
\text { de Moraes } \\
\text { et al. (1996) }\end{array}$ \\
\hline Urochloa humidicola & $\begin{array}{l}\text { Leaves } \\
\text { Roots }\end{array}$ & $\begin{array}{l}-12,20 \\
-12,40\end{array}$ & $\begin{array}{l}\text { Desjardins } \\
\text { et al. (2004) }\end{array}$ \\
\hline
\end{tabular}

Table $6 \quad \delta^{13} \mathrm{C}$ values of grasses in some Amazonian pastures substantial variation in the Cp quantification: for example, a difference of $3 \%$ associated with $\delta \mathrm{P}$ when $\delta \mathrm{t}=-20 \%$ and $\mathrm{Ct}=40 \mathrm{Mg} \mathrm{ha}^{-1}$ implies $4.6 \mathrm{Mg} \mathrm{ha}^{-1}$ of difference in the $\mathrm{Cp}$ estimation, equivalent to more than $10 \%$ of the mean total stock observed under pasture. Given this variability, the accurate determination of $\delta \mathrm{P}$ is essential. However, in many studies, this $\delta \mathrm{P}$ value was not measured and referred to previous studies (e.g. Neill et al., 1997), and considered litter $\delta$ P value rather than roots $\delta \mathrm{P}$ value, although carbon inputs in pasture systems are mainly derived from roots. In addition, the $\delta \mathrm{P}$ variability should increase if different grasses are used for a given chronosequence (Koutika et al., 1997).

\section{Methodological implications}

Some methodological implications can be discussed to reduce the uncertainties associated with the SOC changes after deforestation in Amazonia, which are no doubt applicable to other regions. Indeed, Don et al. (2011) showed that in the humid tropics, studies on SOC dynamics are scarcer in South-East Asia and in Africa than in Amazonia. There is a need for more diachronic studies, which eliminate much of the variability and uncertainty associated with soil properties and management. These studies are expensive, and time is required to obtain valuable results, but this is one of the best ways to reduce uncertainty (Costa Junior et al., 2013; Dimassi et al., 2014), and there is no option whether we want to produce more relevant results that can be used for instance in the modelling of the agroecosytem responses to anthropogenic changes.

We found that the time since deforestation in the forest-cropland comparisons was short (mean 8 years), so that the SOC may not have reached an equilibrium state (Penman et al., 2003; Smith, 2014). Results from older croplands are therefore needed to evaluate the SOC loss over the longer term. Maia et al. (2010) found in south-eastern Amazonia that no-till systems had similar SOC stocks than forest $(+0.1 \pm 17 \%)$, but we believe that extrapolation of these results to the future should be performed with caution because many no-till systems were very young in their study. In this agricultural frontier of southern Amazonia, where agroecosystems are young, we hope that SOC monitoring will continue to provide long-term data.

For pastures, there is a need for studies covering at least 20 years using the isotopic approach, so that a figure for SOC storage in pastures could be proposed for use in long-term modelling. We did not include in our review mixed agroecosystems, for instance integrated crop-livestock systems as studied by Carvalho et al. (2010) in Rondônia and north of Mato Grosso. These 
authors showed that soils in this kind of system could store more SOC than cropland systems or degraded pastures. In other Brazilian biomes, a recent review found same trends (Pinto \& Assad, 2013); further research on these systems is needed in Amazonia. Future research will also be needed to assess SOC dynamics after land-use change on former deforested areas, for instance croplands established after pastures.

Few studies in Amazonia (10 comparisons) determined SOC stocks after deforestation in deep soil layers. But in this biome, the soils are deep and the SOC dynamics after land-use change, in a biogeochemical sense, take place within the entire soil volume (Rumpel \& Kögel-Knabner, 2010; Shi et al., 2013). Sampling the soil to $100 \mathrm{~cm}$ depth rather than $30 \mathrm{~cm}$ as suggested by IPCC (Penman et al., 2003) is desirable, particularly if we want to analyse the SOC change from an environmental perspective (Trumbore, 2009). The balance between loss of the native carbon by mineralization in deep soil horizons and the decomposition of forest roots on the one hand, and on the other hand, the inputs by root flux carbon presumed to be important under pastures and has barely been evaluated in Amazonia. Amazonian soil systems export carbon even under forest by leaching and runoff; in the future, we will also need to measure the effect of deforestation on the leaching of dissolved carbon in small watersheds and check whether such exports are higher than those measured for natural forests by hydrogeochemists (Bardy et al., 2011).

Finally, there is a lack of data about the management of the agroecosystems in Amazonia for SOC study purposes. These data are fundamental for predictive studies by modelling with mechanistic models such as RothC or Century. This is particularly important for the short-term management of studied sites: deforestation method, fire efficiency, woody residues, soil loss by erosion and number of cultivation cycles before pasture establishment, which determine the short-term SOC dynamics. In the medium term, particularly for croplands, knowledge of the intensity of the rotations and data for organic restitutions (crop residues, organic fertilization) should improve the explanation of the SOC variations observed. The comparison between tilled and no-tilled systems needs to be assessed in regard to carbon inputs, which explained most of the variation in SOC stocks between till and no-till systems (Virto et al., 2012). The effect of no-till on SOC storage has been overestimated (Powlson et al., 2014), partly because sampling depth was too superficial in many studies comparing tilled and no-tilled systems (Baker et al., 2007; Dimassi et al., 2014). For pastures, research has to stress the management factors that explain the SOC stock variations observed; the current pasture classifica- tion does not seem adequate to distinguish the SOC dynamics.

\section{SOC policies}

Given the large GHG emissions associated with deforestation in Amazonia, the soil conservation associated with good management of agroecosystems in deforested areas (Grimaldi et al., 2014) is the only achievable target in the short and medium term, to maintain sustainable food production. A goal of high soil carbon stocks is not compatible with high productivity of croplands; in the case of pastures, it involves management intensification with technology, and the current Amazonian organization systems often do not offer these options. On the one hand, some farms are too large, whereas on the other, smallholders have no access to credit or technology transfer (Guedes et al., 2014); however, there are examples where smallholders implement locally sustainable and intensive cropping systems (Arnauld de Sartre et al., 2005). Thus, the carbon issue is related to an adaptation of policies to small regions and socio-economic targets (Brossard \& LópezHernández, 2005). In Brazil, the adoption of Low Carbon Agriculture Plan (ABC Plan) since 2010 shows that henceforth, public policies aim to promote credits for farmers adopting farming systems enhancing carbon storage in soil and biomass, rather than unsustainable agricultural systems (Brando et al., 2013; Pinto \& Assad, 2013).

\section{Concluding remarks}

In Amazonia, agroecosystems establishment after deforestation lead to a slight increase of SOC stocks in pastures and to a slight decrease in croplands. However, uncertainties are high and these systems probably not reached an equilibrium state given the short timescale considered, especially for croplands. We could not relate strong heterogeneity of SOC response after deforestation to pedoclimatic factors or management factors, at best we can assume that improved pastures could gain SOC compared to forest. Nevertheless, SOC derived from pasture grasses measured with isotopic analyses exhibited a relatively coherent accumulation, with an average of $20 \mathrm{MgC} \mathrm{ha}{ }^{-1}$ in twenty years in the layer $0-20 / 30 \mathrm{~cm}$. Our meta-analysis highlights the need for diachronic and long-term studies, and we underline that a large part of uncertainties is linked to the lack of knowledge in the management of agroecosystems. Future research on this topic should also consider mixed agroecosystems, as current data available do not cover the large pattern of cropping systems existing in Amazonia. 


\section{Acknowledgements}

This study was partly funded by the Fond Européen de Développement Régional, the CETIOM (Centre Technique Interprofessionnel des Oléagineux et du Chanvre) and the Guiana Region. K. Fujisaki was funded by an ANRT Scholarship Project (CIFRE N²011-36). English revision by Alan Scaife.

\section{References}

Alegre JC, Cassel DK (1996) Dynamics of soil physical properties under alternative systems to slash-and-burn. Agriculture, Ecosystems \& Environment, 58, 39-48.

Aragão LE, Poulter B, Barlow JB et al. (2014) Environmental change and the carbon balance of Amazonian forests. Biological Reviews, 89, 913-931.

Arnauld de Sartre X, Albaladejo C, Martins P, Veiga I, Grimaldi M (2005) Identification et évaluation de la diversité des modes d'exploitation des milieux en Amazonie orientale. Cahiers Agricultures, 14, 85-89.

Baker JM, Ochsner TE, Venterea RT, Griffis TJ (2007) Tillage and soil carbon sequestration-What do we really know? Agriculture, Ecosystems \& Environment, 118, 1-5.

Balesdent J, Wagner GH, Mariotti A (1988) Soil organic matter turnover in long-term field experiments as revealed by carbon-13 natural abundance. Soil Science Society of America Journal, 52, 118.

Balesdent J, Besnard E, Arrouays D, Chenu C (1998) The dynamics of carbon in particle-size fractions of soil in a forest-cultivation sequence. Plant and Soil, 201, 49-57.

Bardy M, Derenne S, Allard T, Benedetti MF, Fritsch E (2011) Podzolisation and exportation of organic matter in black waters of the Rio Negro (upper Amazon basin, Brazil). Biogeochemistry, 106, 71-88.

Béliveau A, Lucotte M, Davidson R, do Canto Lopes LO, Paquet S (2009) Early Hg mobility in cultivated tropical soils one year after slash-and-burn of the primary forest, in the Brazilian Amazon. Science of the Total Environment, 407, 4480-4489.

Bernoux M, Cerri CC, Neill C, de Moraes JF (1998) The use of stable carbon isotopes for estimating soil organic matter turnover rates. Geoderma, 82, 43-58.

Bernoux M, Feigl BJ, Cerri CC, Geraldes APDA, Fernandes SAP (1999) Soil carbon and nitrogen in a forest - pasture chronosequence from Paragominas. Scientia Agricola, 56, 777-783.

Bouchez J, Galy V, Hilton RG et al. (2014) Source, transport and fluxes of Amazon River particulate organic carbon: insights from river sediment depth-profiles. Geochimica et Cosmochimica Acta, 133, 280-298.

Brando PM, Coe MT, DeFries R, Azevedo AA (2013) Ecology, economy and management of an agroindustrial frontier landscape in the southeast Amazon. Philosophical Transactions of the Royal Society B: Biological Sciences, 368, 20120152.

Brossard M, López-Hernández D (2005) Des indicateurs d'évolution du milieu et des sols pour rendre durable l'usage des savanes d'Amérique du Sud. Natures Sciences Sociétés, 13, 266-278.

Camargo PB, Trumbore SE, Martinelli LA, Davidson EA, Nepstad DC, Victoria RL (1999) Soil carbon dynamics in regrowing forest of eastern Amazonia. Global Change Biology, 5, 693-702.

Carvalho JLN, Raucci GS, Cerri CEP, Bernoux M, Feigl BJ, Wruck FJ, Cerri CC (2010) Impact of pasture, agriculture and crop-livestock systems on soil C stocks in Brazil. Soil and Tillage Research, 110, 175-186.

Cerri CC, Feller C, Balesdent J, Victoria R, Plenecassagne A (1985) Application du traçage isotopique naturel en $13 \mathrm{C}$, à l'étude de la dynamique de la matière organique dans les sols. Comptes Rendus de l'Académie des Sciences de Paris, 300, 423-427.

Cerri CC, Volkoff B, Andreux F (1991) Nature and behaviour of organic matter in soils under natural forest, and after deforestation, burning and cultivation, near Manaus. Forest Ecology and Management, 38, 247-257.

Cerri CEP, Coleman K, Jenkinson DS, Bernoux M, Victoria R, Cerri CC (2003) Modeling soil carbon from forest and pasture ecosystems of Amazon, Brazil. Soil Science Society of America Journal, 67, 1879-1887.

Cerri CEP, Paustian K, Bernoux M, Victoria RL, Melillo JM, Cerri CC (2004) Modeling changes in soil organic matter in Amazon forest to pasture conversion with the Century model. Global Change Biology, 10, 815-832.

Cerri CEP, Cerri CC, Bernoux M, Volkoff B, Rondon MA (2006) Potential of soil carbon sequestration in the Amazonian tropical rainforests. In: Carbon Sequestration in Soils of Latin America (eds Lal R, Cerri CC, Bernoux M, Etchevers J, Cerri CEP), pp. 245-266. The Haword Press, Binghampton, NY.

Cerri CEP, Easter M, Paustian K et al. (2007) Simulating SOC changes in 11 land use change chronosequences from the Brazilian Amazon with RothC and Century models. Agriculture, Ecosystems \& Environment, 122, 46-57.
Cheng W, Parton WJ, Gonzalez-Meler MA et al. (2014) Synthesis and modeling perspectives of rhizosphere priming. New Phytologist, 201, 31-44.

Costa Junior C, Corbeels M, Bernoux M et al. (2013) Assessing soil carbon storage rates under no-tillage: comparing the synchronic and diachronic approaches. Soil and Tillage Research, 134, 207-212.

Dale VH, Pearson SM, Offerman HL, O'Neill RV (1994) Relating patterns of land-use change to faunal biodiversity in the Central Amazon. Conservation Biology, 8, 10271036.

Davidson EA, Ackerman IL (1993) Changes in soil carbon inventories following cultivation of previously untilled soils. Biogeochemistry, 20, 161-193.

Davidson EA, De Abreu Sà TD, Reis Carvalho CJ, De Oliveira Figueiredo R, Kato MSA, Kato OR, Ishida FY (2008) An integrated greenhouse gas assessment of an alternative to slash-and-burn agriculture in eastern Amazonia. Global Change Biology, 14, 998-1007.

Desjardins T, Andreux F, Volkoff B, Cerri CC (1994) Organic carbon and 13C contents in soils and soil size-fractions, and their changes due to deforestation and pasture installation in eastern Amazonia. Geoderma, 61, 103-118.

Desjardins T, Mariotti A, Girardin C, Chauvel A (1996) Changes of the forest-savanna boundary in Brazilian Amazonia during the Holocene revealed by stable isotope ratios of soil organic carbon. Oecologia, 108, 749-756.

Desjardins T, Barros E, Sarrazin M, Girardin C, Mariotti A (2004) Effects of forest conversion to pasture on soil carbon content and dynamics in Brazilian Amazonia. Agriculture, Ecosystems \& Environment, 103, 365-373.

Dimassi B, Mary B, Wylleman R, Labreuche J, Couture D, Piraux F, Cohan J-P (2014) Long-term effect of contrasted tillage and crop management on soil carbon dynamics during 41 years. Agriculture, Ecosystems \& Environment, 188, 134-146.

Do Nascimento NR, Bueno GT, Fritsch E et al. (2004) Podzolization as a deferralitization process: a study of an Acrisol-Podzol sequence derived from Palaeozoic sandstones in the northern upper Amazon Basin. European Journal of Soil Science, 55, 523-538.

Don A, Schumacher J, Freibauer A (2011) Impact of tropical land-use change on soil organic carbon stocks - a meta-analysis. Global Change Biology, 17, 1658-1670.

Eclesia RP, Jobbagy EG, Jackson RB, Biganzoli F, Piñeiro G (2012) Shifts in soil organic carbon for plantation and pasture establishment in native forests and grasslands of South America. Global Change Biology, 18, 3237-3251.

Ellert BH, Janzen HH, VandenBygaart AJ, Bremer E (2007) Measuring change in soil organic carbon storage. In: Soil Sampling and Methods of Analysis, 2nd edn (eds Carter MR, Gregorich EG), pp. 25-38. CRC Press, Boca Raton, FL.

Eva HD, Huber O, Achard F et al. (2005) A Proposal for Defining the Geographical Boundaries of Amazonia. JRC Ispra, Office for Official Publications of the European Communities, Luxembourg.

Fabian P, Kohlpaintner M, Rollenbeck R (2005) Biomass Burning in the Amazon-Fertilizer for the Mountaineous Rain Forest in Ecuador. Environmental Science and Pollution Research, 12, 290-296.

Falesi IC (1976) Ecossistema de Pastagem Cultivada na Amazônia Brasileira. EMBRAPA, Centro de Pesquisa Agropecuária do Trópico Úmido. Belém, Brazil.

Farella N, Lucotte M, Louchouarn P, Roulet M (2001) Deforestation modifying terrestrial organic transport in the Rio Tapajós, Brazilian Amazon. Organic Geochemistry, 32, 1443-1458.

Fearnside PM, Barbosa RI (1998) Soil carbon changes from conversion of forest to pasture in Brazilian Amazonia. Forest Ecology and Management, 108, 147-166.

Feller C, Beare MH (1997) Physical control of soil organic matter dynamics in the tropics. Geoderma, 79, 69-116.

Feller C, Fritsch E, Poss R, Valentin C (1991) Effet de la texture sur le stockage et la dynamique des matières organiques dans quelques sols ferrugineux et ferrallitiques (Afrique de l'Ouest, en particulier). Cahiers ORSTOM. Série Pédologie, 26, 2536.

Fisher MJ, Rao IM, Ayarza MA, Lascano CE, Sanz JI, Thomas RJ, Vera RR (1994) Carbon storage by introduced deep-rooted grasses in the South American savannas. Nature, 371, 236-238.

Frazão LA, Paustian K, Pellegrino Cerri CE, Cerri CC (2013) Soil carbon stocks and changes after oil palm introduction in the Brazilian Amazon. Global Change Biology Bioenergy, 5, 384-390.

Freitas HA, Pessenda LCR, Aravena R, Gouveia SEM, de Souza Ribeiro A, Boulet R (2001) Late quaternary vegetation dynamics in the Southern Amazon Basin inferred from carbon isotopes in soil organic matter. Quaternary Research, 55, 39 46.

Fritsch E, Balan E, Nascimento NR et al. (2011) Deciphering the weathering processes using environmental mineralogy and geochemistry: towards an integrated model of laterite and podzol genesis in the Upper Amazon Basin. Comptes Rendus Geoscience, 343, 188-198. 
Fujisaka S, Castilla C, Escobar G, Rodrigues V, Veneklaas E, Thomas R, Fisher M (1998) The effects of forest conversion on annual crops and pastures: estimates of carbon emissions and plant species loss in a Brazilian Amazon colony. Agriculture, Ecosystems \& Environment, 69, 17-26.

Gardi C, Angelini M, Barceló S et al. (2014) Atlas de suelos de América Latina y el Caribe, Comisión Europea, Oficina de Publicaciones de la Unión Europea edn. L2995 Luxembourg.

Grace J, Mitchard E, Gloor E (2014) Perturbations in the carbon budget of the tropics. Global Change Biology, 20, 3238-3255.

Grimaldi M, Sarrazin M, Chauvel A et al. (1993) Effets de la déforestation et des cultures sur la structure des sols argileux d'Amazonie brésilienne. Agricultures: Cahiers d'Etudes et de Recherches Francophones, 2, 36-47.

Grimaldi M, Schroth G, Teixeira WG, Huwe B (2003) Soil structure. In: Trees, Crops, and Soil Fertility : Concepts and Research Methods (eds Schroth G, Sinclair FL), pp. 191-203. CABI, Wallingford.

Grimaldi M, Oszwald J, Dolédec S et al. (2014) Ecosystem services of regulation and support in Amazonian pioneer fronts: searching for landscape drivers. Landscape Ecology, 29, 311-328.

Guedes GR, VanWey LK, Hull JR, Antigo M, Barbieri AF (2014) Poverty dynamics, ecological endowments, and land use among smallholders in the Brazilian Amazon. Social Science Research, 43, 74-91.

Guo LB, Gifford RM (2002) Soil carbon stocks and land use change: a meta analysis. Global Change Biology, 8, 345-360.

Holmes KW, Chadwick OA, Kyriakidis PC, deFilho S, Eliomar P, Soares JV, Roberts DA (2006) Large-area spatially explicit estimates of tropical soil carbon stocks and response to land-cover change. Global Biogeochemical Cycles, 20, doi:10.1029/ 2005 GB002507.

Horbe AMC, Horbe MA, Suguio K (2004) Tropical Spodosols in northeastern Amazonas State, Brazil. Geoderma, 119, 55-68.

IUSS Working Group (2007) World Reference Base for Soil Resources 2006, First Update 2007. World Soil Resources Reports No. 103. FAO, Rome.

Janssen BH, Wienk JF (1990) Mechanized annual cropping on low fertility acid soils in the humid tropics: a case study of the Zanderij soils in Suriname, vol. 90. Wageningen Agricultural University Papers, Wageningen.

Koutika L-S, Bartoli F, Andreux F, Cerri CC, Burtin G, Choné T, Philippy R (1997) Organic matter dynamics and aggregation in soils under rain forest and pastures of increasing age in the eastern Amazon Basin. Geoderma, 76, 87112

Lal R, Kimble JM, Follett RF, Stewart BA (1997) Soil Processes and the Carbon Cycle. CRC Press, Boca Raton, Boston

Lisboa CC, Conant RT, Haddix ML, Cerri CEP, Cerri CC (2009) Soil carbon turnover measurement by physical fractionation at a forest-to-pasture chronosequence in the Brazilian Amazon. Ecosystems, 12, 1212-1221.

Luizão RCC, Bonde TA, Rosswall T (1992) Seasonal variation of soil microbial biomass-The effects of clearfelling a tropical rainforest and establishment of pasture in the central Amazon. Soil Biology and Biochemistry, 24, 805-813.

Maia SMF, Ogle SM, Cerri CEP, Cerri CC (2009) Effect of grassland management on soil carbon sequestration in Rondônia and Mato Grosso states, Brazil. Geoderma, 149, 84-91.

Maia SMF, Ogle SM, Cerri CC, Cerri CEP (2010) Changes in soil organic carbon storage under different agricultural management systems in the Southwest Amazon Region of Brazil. Soil and Tillage Research, 106, 177-184.

Malhi Y, Roberts JT, Betts RA, Killeen TJ, Li W, Nobre CA (2008) Climate change, deforestation, and the fate of the Amazon. Science, 319, 169-172.

Mann LK (1986) Changes in soil carbon storage after cultivation. Soil Science, 142, 279-288.

Melo AWF (2003) Avaliação do Estoque e Composição Isotópica do Carbono do Solo no Acre Dissertação (mestrado), Escola Superior de Agricultura Luiz de Queiroz, Piracicaba.

de Moraes JFL, Volkoff B, Cerri CC, Bernoux M (1996) Soil properties under Amazon forest and changes due to pasture installation in Rondônia, Brazil. Geoderma, 70, 63-81.

Mosquera O, Buurman P, Ramirez BL, Amezquita MC (2012) Carbon stocks and dynamics under improved tropical pasture and silvopastoral systems in Colombian Amazonia. Geoderma, 189-190, 81-86.

Murty D, Kirschbaum MUF, Mcmurtrie RE, Mcgilvray H (2002) Does conversion of forest to agricultural land change soil carbon and nitrogen? a review of the literature. Global Change Biology, 8, 105-123.
Neill C, Davidson EA (2000) Soil carbon accumulation or loss following deforestation for pasture in the Brazilian Amazon. In: Global Climate Change and Tropical Ecosystems (eds Kimble J, Stewart B), pp. 197-211. CRC Press, Boca Raton, FL.

Neill C, Melillo JM, Steudler PA, Cerri CC, de Moraes JFL, Piccolo MC, Brito M (1997) Soil carbon and nitrogen stocks following forest clearing for pasture in the southwestern Brazilian Amazon. Ecological Applications, 7, 1216-1225.

Nepstad D, Soares-Filho BS, Merry F et al. (2009) The end of deforestation in the Brazilian Amazon. Science, 326, 1350-1351.

Nepstad D, McGrath D, Stickler C et al. (2014) Slowing Amazon deforestation through public policy and interventions in beef and soy supply chains. Science, 344, 1118-1123.

Nobre CA, Obregón GO, Marengo JA, Fu R, Poveda G (2009) Characteristics of Amazonian climate: main features. In: Amazonia and Global Change (eds Keller M, Bustamante M, Gash J, Dias PS), pp. 149-162. American Geophysical Union, Washington, DC.

Pan Y, Birdsey RA, Fang J et al. (2011) A large and persistent carbon sink in the World's Forests. Science, 333, 988-993.

Paterson E (2003) Importance of rhizodeposition in the coupling of plant and microbial productivity. European Journal of Soil Science, 54, 741-750.

Peel MC, Finlayson BL, McMahon TA (2007) Updated world map of the Köppen-Geiger climate classification. Hydrology and Earth System Sciences, 11, 1633-1644.

Penman J, Gytarsky M, Hiraishi T et al. (2003) Good Practice Guidance for Land use, Land-use Change and Forestry. Institute for Global Environmental Strategies, Kanagawa, Japan.

Pérez MAP, Moreira-Turcq P, Gallard H, Allard T, Benedetti MF (2011) Dissolved organic matter dynamic in the Amazon basin: sorption by mineral surfaces. Chemical Geology, 286, 158-168.

Perrin A-S, Fujisaki K, Petitjean C et al. (2014) Conversion of forest to agriculture in Amazonia with the chop-and-mulch method: does it improve the soil carbon stock? Agriculture, Ecosystems \& Environment, 184, 101-114.

Pinto HS, Assad ED (2013) Mitigando Mudanças Climáticas no Setor Agrícola. Estoques de carbono nos solos do Brasil, Embaixada Britânica, Embrapa, UNICAMP.

Powers JS, Veldkamp E (2005) Regional variation in soil carbon and $\delta 13 \mathrm{C}$ in forests and pastures of northeastern Costa Rica. Biogeochemistry, 72, 315-336.

Powlson DS, Stirling CM, Jat ML, Gerard BG, Palm CA, Sanchez PA, Cassman KG (2014) Limited potential of no-till agriculture for climate change mitigation. Nature Climate Change, 4, 678-683.

Quesada CA, Lloyd J, Anderson LO, Fyllas NM, Schwarz M, Czimczik CI (2011) Soils of Amazonia with particular reference to the RAINFOR sites. Biogeosciences, 8 , 1415-1440.

Rumpel C, Kögel-Knabner I (2010) Deep soil organic matter-a key but poorly understood component of terrestrial C cycle. Plant and Soil, 338, 143-158.

Salimon C, Wadt PG, Alves S (2009) Decrease in carbon stocks in an oxisol due to land use and cover change in southwestern Amazon. Ambiente e Agua, 4, 57-65.

Shi S, Zhang W, Zhang P, Yu Y, Ding F (2013) A synthesis of change in deep soil organic carbon stores with afforestation of agricultural soils. Forest Ecology and Management, 296, 53-63.

Skole D, Tucker C (1993) Tropical deforestation and habitat fragmentation in the Amazon. Satellite data from 1978 to 1988. Science, 260, 1905-1910.

Smith P (2008) Land use change and soil organic carbon dynamics. Nutrient Cycling in Agroecosystems, 81, 169-178.

Smith P (2014) Do grasslands act as a perpetual sink for carbon? Global Change Biology, 20, 2708-2711.

Soubiès F (1979) Existence d'une phase sèche en Amazonie brésilienne datée par la présence de charbons dans les sols (6000-3000 ans B.P.). Cahiers ORSTOM. Série Géologie, 11, 133-148.

Souza Braz AM, Fernandes AR, Alleoni LRF (2013) Soil attributes after the conversion from forest to pasture in Amazon. Land Degradation \& Development, 24, 33-38.

Stocking MA (2003) Tropical soils and food security: the next 50 years. Science, 302, 1356-1359.

Trumbore S (2009) Radiocarbon and soil carbon dynamics. Annual Review of Earth and Planetary Sciences, 37, 47-66.

Trumbore SE, Davidson EA, Barbosa de Camargo P, Nepstad DC, Martinelli LA (1995) Belowground cycling of carbon in forests and pastures of eastern Amazonia. Global Biogeochemical Cycles, 9, 515-528.

Virto I, Barré P, Burlot A, Chenu C (2012) Carbon input differences as the main factor explaining the variability in soil organic $\mathrm{C}$ storage in no-tilled compared to inversion tilled agrosystems. Biogeochemistry, 108, 17-26. 